UDC 539.3

\title{
BOUNDARY ELEMENT APPROACHES TO THE PROBLEM OF 2-D NON-STATIONARY ELASTIC VIBRATIONS
}

\author{
Yu.V. Vorona, \\ Candidate of Science (Engineering)
}

A.A. Kozak

Kyiv National University of Construction and Architecture
31, Povitroflotsky ave., Kyiv, Ukraine, 03680

DOI: $10.32347 / 2410-2547.2020 .104 .321-327$

\begin{abstract}
Two boundary element approaches are used to solve the problem on non-stationary vibrations of elastic solids. The first approach is based on the transition to the frequency domain by means of a Fourier series expansion. The second approach is associated with the direct solution of a system of time-dependent boundary integral equations, with a piecewise constant approximation of the dependence of the unknowns on time. In both cases, a collocation scheme is used to algebraize the integral equations, and the difficulties associated with the calculation of singular integrals are overcome by replacing the kernels with the initial segment of the Maclaurin series. After such a replacement, the kernels take the form of a sum, the first term of which is the corresponding fundamental solution of the statics problem while other terms are regular. Since integration of static kernels is not difficult the problem of calculating the diagonal coefficients of the SLAE turns out to be solved. The developed techniques are compared in the process of dynamics analysis solving of elastic media with two cylindrical cavities. The boundary of one of the cavities is subjected to a radial impulse load, which varies according to the parabolic law. Both approaches have shown the similar effectiveness and qualitative consistency.
\end{abstract}

Keywords: time-dependent boundary integral equations, frequency domain, Hankel functions, Maclaurin series, impulse loading.

The Boundary Element Method (BEM) is an effective tool for solving the problem of vibrations of elastic bodies with different cavities and inclusions. In this case, the solution of the problem can be obtained in two ways. In the first case, the Fourier transform is used to convert the problem into a frequency domain, while in the second case, a time-step procedure is used. In both cases, the algorithmic basis of the problem is the boundary analogue of the Somigliana identity for displacements. The identity links known displacements and stresses at the boundary points with those not unspecified by boundary conditions. The resolving equation describing two-dimensional harmonic vibrations of an elastic mass body, in the absence of mass loads, is as follows

$$
\frac{1}{2} u_{j}^{*}(\vec{x}, \omega)=\int_{\Gamma} \tau_{k}^{*}(\vec{y}, \omega) U_{j k}(\vec{x}, \vec{y}, \omega) d \Gamma_{y}-\int_{\Gamma} u_{k}^{*}(\vec{y}, \omega) T_{j k}(\vec{x}, \vec{y}, \omega) d \Gamma_{y}, j, k=1,2,
$$

where $\omega$ is the circular frequency of vibrations; $\vec{x}\left\{x_{1}, x_{2}\right\}, \vec{y}\left\{y_{1}, y_{2}\right\} \in \Gamma ; \Gamma-$ boundary of the area occupied by the body; $u_{j}(\vec{x}, \omega), q_{j}(\vec{x}, \omega)$ are respectively complex amplitudes of displacements and stresses at the boundary; $U_{j k}(\vec{x}, \vec{y}, \omega)$ - the fundamental solution of the problem $[1,2]$, which is given by the expression

(C) Vorona Yu.V., Kozak A.A. 


$$
\begin{gathered}
U_{j k}(\vec{x}, \vec{y}, \omega)=\frac{i}{4 \mu}\left\{\delta_{j k}\left[H_{0}^{(1)}\left(\varphi_{1}\right)-\frac{H_{1}^{(1)}\left(\varphi_{2}\right)}{\varphi_{2}}+\alpha \frac{H_{1}^{(1)}\left(\varphi_{1}\right)}{\varphi_{1}}\right]+\right. \\
+\frac{i}{4 \mu} r,{ }_{j} r, k\left[H_{2}^{(1)}\left(\varphi_{2}\right)-\alpha H_{2}^{(1)}\left(\varphi_{1}\right)\right]
\end{gathered}
$$

$\varphi_{j}=\frac{\omega r}{C_{j}} ; C_{2}=\sqrt{\frac{\mu}{\rho}} ; C_{1}=\sqrt{\frac{\lambda+2 \mu}{\rho}} ; \alpha=\frac{C_{2}^{2}}{C_{1}^{2}} ; \rho$ - material density; $\lambda$ and $\mu$ - Lame constants; $\quad r,{ }_{j}=\frac{\partial r}{\partial y_{j}}=\frac{y_{j}-x_{j}}{r} ; \quad r^{2}=\left(y_{1}-x_{1}\right)^{2}+\left(y_{2}-x_{2}\right)^{2} ; \quad T_{j k}(\vec{x}, \vec{y}, \omega) \quad-$ generalized derivative of the fundamental solution (stresses at the sites with normal $n_{j}(\vec{y})$ that arise in elastic two-dimensional media due to the action in the point $\vec{x}$ of concentrated unit force in the direction $x_{k} ; H_{m}^{(1)}$ is the Hankel function of the first kind.

In accordance with the collocation procedure of BEM the boundary is represented as a set of elements and a hypothesis defining how the unknown quantities change within each BE (i.e. basic function) is introduced. Then a set of poles $\vec{x}_{l}$ is assigned, agreed with the introduced hypothesis, and then equations (1) are written in each of the poles in turn. The result of this procedure is a system of linear algebraic equations with respect to unknown values of amplitudes of displacements and stresses at collocation points $\vec{x}_{l}$. The system coefficients are integrals over boundary elements of product of kernel $U_{j k}(\vec{x}, \vec{y}, \omega)$ or $T_{j k}(\vec{x}, \vec{y}, \omega)$ and the corresponding basic function.

When the distance $r$ between the source $\vec{x}$ point and the integration point $\vec{y}$ tends to zero, i.e., if the pole is located at the same BE on which the integration is carried out, the Hankel functions, and with them the sub-integral expressions, take infinitely large values, which makes it impossible to calculate the diagonal system matrix coefficients using numerical integration. To overcome this obstacle, the Hankel functions are approximately replaced by the initial segments of the Maclaurin series. After such a replacement the kernels can be represented as follows [3]

$$
U_{j k}(\vec{x}, \vec{y}, \omega) \approx U_{j k}^{s}(\vec{x}, \vec{y})+U_{j k}^{*}(\vec{x}, \vec{y}, \omega) ; T_{j k}(\vec{x}, \vec{y}, \omega) \approx T_{j k}^{s}(\vec{x}, \vec{y})+T_{j k}^{*}(\vec{x}, \vec{y}, \omega),
$$

where $U_{j k}^{s}(\vec{x}, \vec{y})$ and $T_{j k}^{s}(\vec{x}, \vec{y})$ are respectively the fundamental solution of the static 2D problem of and its generalized derivative.

Since integration of the kernels of the static problem does not cause difficulties, and regular additives $U_{j k}^{*}(\vec{x}, \vec{y}, \omega), T_{j k}^{*}(\vec{x}, \vec{y}, \omega)$ can be determined with any degree of accuracy, the problem of algebraization of the system of boundary integral equations (1) can be considered solved in the first approach. 
The second approach requires solving a system of time-dependent boundary integral equations, which under zero initial conditions and the absence of mass forces can be written as follows

$$
\begin{aligned}
& \frac{1}{2} u_{j}(\vec{x}, t)=\int_{0}^{t^{+}} \int_{\Gamma} U_{j k}(\vec{x}, \vec{y}, t-\tau) q_{k}(\vec{y}, \tau) d \Gamma_{y} d \tau- \\
& -\int_{0}^{t^{+}} \int_{\Gamma} T_{j k}(\vec{x}, \vec{y}, t-\tau) u_{k}(\vec{y}, \tau) d \Gamma_{y} d \tau,
\end{aligned}
$$

where $U_{k j}(r, t)=\frac{1}{2 \pi \rho}\left[\frac{H\left(C_{1} t-r\right)}{C_{1} r^{2}} f_{k j}^{(1)}(\vec{x}, \vec{y}, t)+\frac{H\left(C_{2} t-r\right)}{C_{2} r^{2}} f_{k j}^{(2)}(\vec{x}, \vec{y}, t)\right], \quad H(\tau)$ is Heaviside step function; $f_{k j}^{(1)}(r, t)=\left(2 d_{1}+\frac{r^{2}}{d_{1}}\right) r_{, k} r,{ }_{j}-\delta_{k j} d_{1}$, $f_{k j}^{(2)}(r, t)=\left(2 d_{2}+\frac{r^{2}}{d_{2}}\right) r_{, k} r,{ }_{j}-\delta_{k j}\left(d_{2}+\frac{r^{2}}{d_{2}}\right), d_{1}=\sqrt{\left(C_{1} t\right)^{2}-r^{2}}, d_{2}=\sqrt{\left(C_{2} t\right)^{2}-r^{2}}$, $T_{j k}(r, \tau)$ is a generalized derivative of the fundamental solution $U_{j k}(r, \tau)$.

The peculiarity of this approach is that time is one of variables, on which the solution depends. Accordingly, it is necessary to divide the time interval into separate intervals and approximate the unknown within each interval. Assuming that the boundary stresses at each step remain constant, time integration of the both terms in the right side of equation (4) can be done analytically [4]. Moreover, the resulting expressions can also be presented in a form similar to that of representation (3), i.e., as a sum of the corresponding static kernel and some regular additive. Thus, even in this case, it is possible to overcome all the fundamental obstacles to the numerical solution of the problem [4].

Comparison of the developed algorithms was carried out using the problem about non-stationary vibrations of elastic space with two circular cylindrical cavities of radius $\mathrm{R}=3 \mathrm{~m}$. Boundary of the left cavity is exposed to radial influence of parabolic impulse, set by the formula $q_{R}(t)=4 \frac{q t(T-t)}{T^{2}}$ (Fig. 1). Time of the impulse action is $T=20 R / C_{1}=0.0108 \mathrm{~s}$.

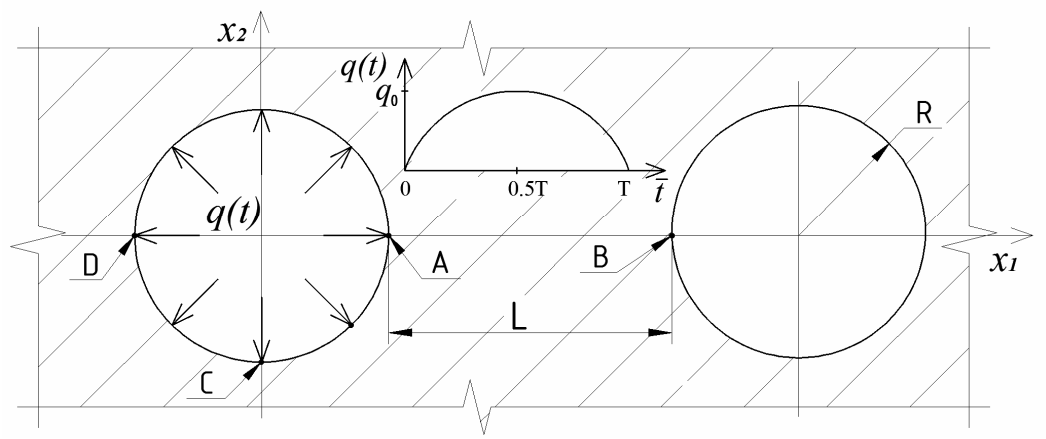

Fig. 1. Calculated area 
The results of calculations are shown in Figures 2, 3. Graphs marked with figures 1 and 4 are the curves obtained as a result of the system (4) solution. Figures 2 and 5 denote the graphs built within the first approach using 12 terms of the Fourier series, and figures 3 and 6 denote the graphs, for the construction of which 4 terms of the series were kept. At the same time, the diagrams 1,2,3 characterize the stress-strain state parameters at the point $A$, and the diagrams 4, 5, 6 correspond to the same parameters at the point $B$ of the boundary (Fig. 1).

Extreme values of normalized parameters of stress-strain state, obtained with the help of two approaches, are contained in Tables 1-4.

The values of radial displacements $u_{R}$ and tangential stresses $\sigma_{S}$ were normalized according to the formulas $U_{R}^{n}=u_{R} \frac{\mu}{q R}$ and $\sigma_{s}^{n}=\frac{\sigma_{s}}{q}$ respectively. The values $U_{R}^{n, t}, \sigma_{s}^{n, t}$ are obtained by solving the system of time-dependent boundary integral equations (2nd approach) and $U_{R}^{n, \omega}(m), \sigma_{s}^{n, \omega}(m)$ are obtained using transition to the frequency domain (1st approach) while value $m$ corresponds to the number sine waves.

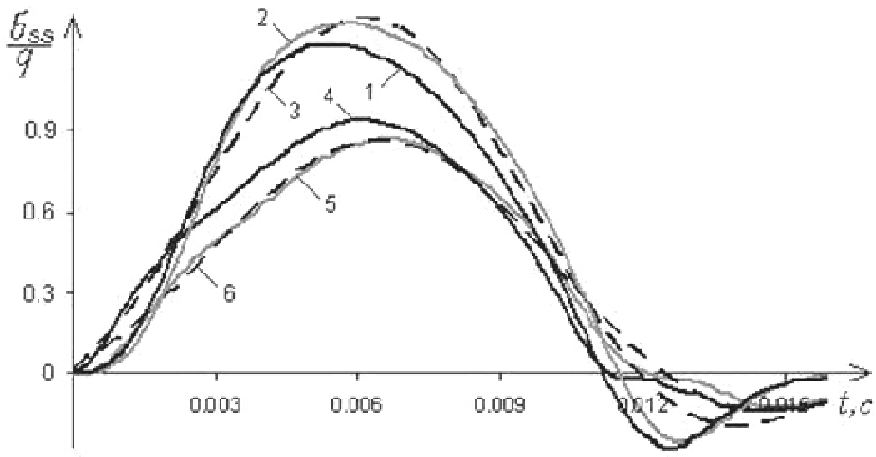

Fig. 2. Radial displacements in points $A$ and $B$ of the boundary when $L=3 \mathrm{~m}$

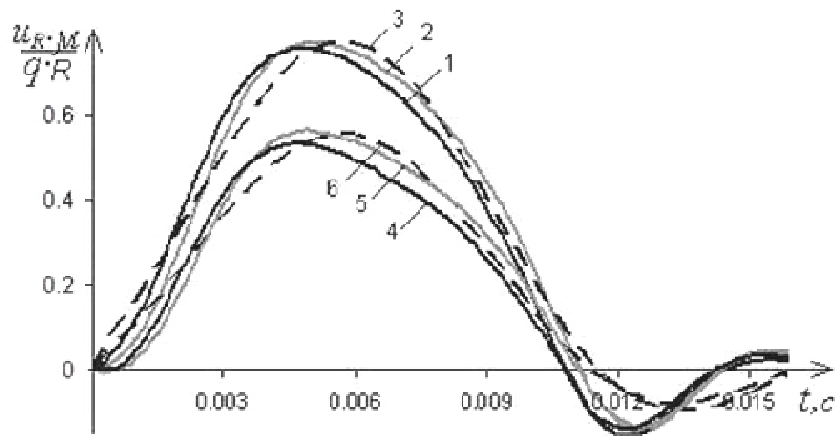

Fig. 3. Tangential stresses in points $A$ and $B$ of the boundary when $L=3 \mathrm{~m}$ 
Table 1

Normalized radial displacements at the points of the boundary

\begin{tabular}{|c|c|c|c|c|c|c|}
\hline Point & $U_{R, \max }^{n, t}$ & $\begin{array}{c}U_{R, \max }^{n, w} \\
(4)\end{array}$ & $\begin{array}{c}U_{R, \max }^{n, w} \\
(12)\end{array}$ & $U_{R, \min }^{n, t}$ & $\begin{array}{c}U_{R, \min }^{n, w} \\
(4)\end{array}$ & $\begin{array}{c}U_{R, \min }^{n, w} \\
(12)\end{array}$ \\
\hline$A$ & 0.764 & 0.777 & 0.775 & -0.155 & -0.096 & -0.144 \\
\hline$B$ & 0.502 & 0.521 & 0.502 & -0.043 & -0.055 & -0.036 \\
\hline$C$ & 0.526 & 0.528 & 0.524 & -0.080 & -0.057 & -0.071 \\
\hline$D$ & 0.536 & 0.562 & 0.567 & -0.134 & -0.078 & -0.135 \\
\hline
\end{tabular}

Table 2

Normalized tangential stresses at the border points. $L=3 \mathrm{~m}$

\begin{tabular}{|c|c|c|c|c|c|c|}
\hline Point & $\sigma_{s, \max }^{n, t}$ & $\begin{array}{c}\sigma_{s, \max }^{n, w} \\
(4)\end{array}$ & $\begin{array}{c}\sigma_{s, \max }^{n, w} \\
(12)\end{array}$ & $\sigma_{s, \min }^{n, t}$ & $\begin{array}{c}\sigma_{s, \min }^{n, w} \\
(4)\end{array}$ & $\begin{array}{c}\sigma_{s, \min }^{n, w} \\
(12)\end{array}$ \\
\hline$A$ & 0.929 & 0.855 & 0.806 & -0.144 & -0.138 & -0.131 \\
\hline$B$ & 1.288 & 1.248 & 1.250 & -0.262 & -0.168 & -0.249 \\
\hline$C$ & 1.046 & 1.065 & 0.993 & -0.130 & -0.118 & -0.114 \\
\hline$D$ & 1.202 & 1.302 & 1.283 & -0.273 & -0.199 & -0.255 \\
\hline
\end{tabular}

Table 3

Normalized radial displacements at border points. $L=6 \mathrm{~m}$

\begin{tabular}{|c|c|c|c|c|c|c|}
\hline Point & $U_{R, \max }^{n, t}$ & $\begin{array}{c}U_{R, \max }^{n, w} \\
(4)\end{array}$ & $\begin{array}{c}U_{R, \max }^{n, w} \\
(12)\end{array}$ & $U_{R, \min }^{n, t}$ & $\begin{array}{c}U_{R, \min }^{n, w} \\
(4)\end{array}$ & $\begin{array}{c}U_{R, \min }^{n, w} \\
(12)\end{array}$ \\
\hline$A$ & 0.619 & 0.625 & 0.625 & -0.105 & -0.085 & -0.102 \\
\hline$B$ & 0.511 & 0.527 & 0.509 & -0.053 & -0.048 & -0.045 \\
\hline$C$ & 0.531 & 0.527 & 0.530 & -0.077 & -0.059 & -0.070 \\
\hline$D$ & 0.312 & 0.323 & 0.325 & -0.104 & -0.063 & -0.098 \\
\hline
\end{tabular}

Table 4

Normalized tangential stresses at the border points. $L=6 \mathrm{~m}$

\begin{tabular}{|c|c|c|c|c|c|c|}
\hline Point & $\sigma_{s, \text { max }}^{n, t}$ & $\begin{array}{c}\sigma_{s, \text { max }}^{n, w} \\
(4)\end{array}$ & $\begin{array}{c}\sigma_{s, \max }^{n, w} \\
(12)\end{array}$ & $\sigma_{s, \min }^{n, t}$ & $\begin{array}{c}\sigma_{s, \min }^{n, w} \\
(4)\end{array}$ & $\begin{array}{c}\sigma_{s, \text { min }}^{n, w} \\
(12)\end{array}$ \\
\hline$A$ & 1.054 & 1.030 & 0.992 & -0.120 & -0.116 & -0.970 \\
\hline$B$ & 1.234 & 1.183 & 1.182 & -0.225 & -0.169 & -0.211 \\
\hline$C$ & 1.122 & 1.076 & 1.060 & -0.147 & -0.106 & -0.129 \\
\hline$D$ & 0.550 & 0.576 & 0.583 & -0.151 & -0.119 & -0.144 \\
\hline
\end{tabular}

The data presented in the figures and tables show satisfactory qualitative consistency of the data obtained using different approaches. It should be noted that as the number of members of the Fourier series increases, the diagrams obtained in 
the first approach become more and more similar to the curves using the solution of the time-dependent boundary integral equations (4), i.e., using relations of the second approach.

\section{REFERENCES}

1. Brebbia C.A., Telles J.C.F., Wrobel L.C. Boundary Elements Techniques. Berlin: SpringerVerlag, 1984. rfield R. Boundary Elements Methods in Engineering Science. - London: McGraw-Hill, 1981. - 464 p.

2. Banerjee P.K., Butterfield R. Boundary Elements Methods in Engineering Science. - London: McGraw-Hill, 1981. - 452 p.

3. Vorona Yu.V, Kozak A.A., Chernenko O.S. Гранично-елементна методика дослідження динамічного НДС пружних масивів [Boundary elements technique for the analysis of 2D elastic solids dynamics (in Ukrainian)] // Opir materialiv i teoriya sporud (Strength of Materials and Theory of Structures). - 2014. - Issue 93. - P. 27-36.

4. Dominguez J. Boundary Element in Dynamics. - Southampton, Boston: Computational Mechanics Publications, 1993. - 454 p

Стаття надійшла до редакиї 05.06.2020

Ворона Ю.В., Козак А.А.

\section{ГРАНИЧНОЕЛЕМЕНТНІ ПІДХОДИ ДО ЗАДАЧІ ПРО НЕСТАЦІОНАРНІ ПРУЖНІ КОЛИВАННЯ У ДВОВИМІРНІЙ ПОСТАНОВЦІ}

Для аналізу нестаціонарних коливань пружних масивів використовуються два граничноелементні підходи. Перший пов'язаний з переходом в частотну область, а другий реалізує процедуру інтегрування за часом. Проведено порівняння методів при вирішенні задачі про імпульсне навантаження пружного середовища 3 двома циліндричними порожнинами.

Ключові слова: гранично-часові інтегральні рівняння, частотна область, функції Ганкеля, ряд Маклорена, імпульсне навантаження.

\section{Ворона Ю.В., Козак А.А.}

ГРАНИЧНОЭЛЕМЕНТНЫЕ ПОДХОДЫ К ЗАДАЧЕ ПРО НЕСТАЦИОНАРНЫЕ УПРУГИЕ КОЛЕБАНИЯ В ДВУМЕРНОЙ ПОСТАНОВКЕ

Для анализа нестационарных колебаний упругих массивов используются два граничноэлементных подхода. Первый из них связан с переходом в частотную область, а второй реализует процедуру интегрирования по времени. Проведено сравнение методов при решении задачи об импульсном нагружении упругой среды с двумя цилиндрическими полостями.

Ключевые слова: гранично-временные интегральные уравнения, частотная область, функции Ганкеля, ряд Маклорена, импульсное нагружение.

\section{УДК 539.}

Ворона Ю.В., Козак А.А. Граничноелементні підходи до задачі про нестаціонарні пружні коливання у двовимірній постановці // Опір матеріалів і теорія споруд: наук.-техн. збірник. - К.: КНУБА, 2020. - Вип. 104. - С. 321-327.

В процесі дослідження нестаціонарних коливань пружного середовища з двома циліндричними порожнинами під дією імпульсного навантаження порівнюються між собою два граничноелементні підходи.

Таб. 4. Рис. 1. Бібліогр. 4 назв. 
UDC 539.3

Vorona Yu.V., Kozak A.A. Boundary element approaches to the problem of 2-D non-stationary elastic vibrations // Strength of Materials and Theory of Structures: Scientific-and-technical collected articles. - K.: KNUBA, 2020. - Issue 104. - P. 321-327.

Two boundary element approaches are compared in the process of analysis of elastic media with two cylindrical cavities response to impulse loading.

Tab. 4. Fig. 1. Ref. 4 items.

УДК 539.

Ворона Ю.В., Козак А.А. Граничноэлементные подходи к задаче про нестационарные упругие колебания в двумерной постановке // Опір матеріалів і теорія споруд: наук.-техн. збірник. - К.: КНУБА, 2020. - Вип. 104. - С. 321-327.

При исследовании нестационарных колебаний упругой среды с двумя иилиндрическими полостями под действием импульсной нагрузки сравниваются между собой два граничноэлементных подхода.

Таб. 4. Рис. 1. Библиогр. 4 назв.

Автор: кандидат технічних наук, старший науковий співробітник, професор кафедри будівельної механіки КНУБА ВОРОНА Юрій Володимирович;

Адреса робоча: 03680, Київ, Украӥна, м. Киӥв, Повітрофлотський пр. 31, Київський національний університет будівнищтва і архітектури, ВОРОНІ Юрію Володимировичу;

Робочий тел.: +38(044)245-48-29;

Мобільний тел.: +38(050)750-13-61;

E-mail: vorona.iuv@knuba.edu.ua

ORCID ID: https://orcid.org/0000-0001-8130-7204

Автор: асистент кафедри будівельної механіки КНУБА КОЗАК Андрій Анатолійович;

Адреса робоча: 03680, Київ, Украӥна, м. Київ, Повітрофлотський пр. 31, Київський національний університет будівниитва і архітектури, КОЗАКУ Андрію Анатолійовичу;

Робочий тел.: +38(044)248-32-37;

Мобільний тел.: +38(066)199-70-36;

E-mail: kozak.aa@knuba.edu.ua

ORCID ID: https://orcid.org/0000-0002-3192-1430 